\title{
PENTOPIKALAN DALAM BAHASA PAKPAK-DAIRI
}

\author{
Ida Basaria \\ FIB Universitas Sumatera Utara \\ email: ida1@usu.ac.id
}

\begin{abstract}
Abstrak
Penelitian ini bertujuan mendeskripsikan pentopikalan dalam bahasa Pakpak-Dairi sebagai proses pragmatis-sintaksis pengubahan unsur bukan topik menjadi topik. Data penelitian ini berupa data lisan dan tulis penggunaan bahasa Pakpak-Dairi. Analisis data mengunakan metode agih dengan teknik ganti dan teknik ubah-ujud. Hasil penelitian sebagai berikut. Pertama, pada bahasa Pakpak-Dairi ditemukan argumen inti dan argumen berupa relasi oblik yang dapat ditonjolkan posisinya ke depan. Pada proses penonjolan argumen inti, terjadi apa yang disebut sebagai pentopikalan. Sebaliknya, pada proses penonjolan argumen relasi oblik tidak terjadi proses pentopikalan, tetapi hanya proses pengedepanan (fronting) atau proses pelepasan ke kiri (left-dislocation). Kedua, bahasa Pakpak-Dairi mempunyai word order V-O-S sebagai unmarked construction dan juga bentuk pentopikalan (O-S-V) sebagai marked construction. Dengan demikian disimpulkan bahwa bahasa Pakpak Dairi termasuk kelompok tipologi bahasa yang tidak menonjolkan subjek dan tidak menonjolkan topik.
\end{abstract}

Kata kunci: pentopikalan, fronting, left-dislocation, unmarked and marked construction

\section{TOPICALIZATION IN THE PAKPAK-DAIRI LANGUAGE}

\begin{abstract}
This study aims to describe topicalization in the Pakpak-Dairi language as a pragmaticsyntactic process that changes elements of non-topic into topic. The data were spoken and written data on the use of the Pakpak-Dairi language. They were analyzed by means of the distribution method using the substitution and form-changing techniques. The results of the study are as follows. First, in the Pakpak-Dairi language there are core arguments and those in the form of the oblique relation that can be emphasized through fronting. The emphasis of core arguments is made through topicalization. On the other hand, the emphasis of oblique relation arguments is made not through topicalization, but through fronting or left-dislocation. Second, the Pakpak-Dairi language has the V-O-S word order as an unmarked construction and the topicalization (O-S-V) form as a marked construction. Therefore, it can be concluded that the Pakpak Dairi language belongs to the typology group of languages not emphasizing the subject and topic.
\end{abstract}

Keywords: topicalization, fronting, left-dislocation, unmarked and marked constructions

\section{PENDAHULUAN}

Bahasa dapat dikelompokkan dalam batasan-batasan ciri khas strukturalnya dan ditetapkan pengelompokan luas berdasarkan sejumlah fitur yang saling berhubungan. Greenberg dalam Mallinson dan Blake (1981:5) menunjukkan bahwa bahasa-bahasa dapat dikelompokkan me-nurut tata urut dasar (basic order) subjek, objek, dan verba (S, O, V). Greenberg mengusulkan suatu tipologi yang di-sebutnya sebagai Tipologi Urutan 
Dasar (Basic Order) yang menyimpulkan ada enam pola kalimat yaitu SVO, SOV, VSO, VOS, OSV, OVS. Bahasa Latin dan bahasa Rusia mempergunakan keenam pola tersebut. Bahasa-bahasa lain ada yang hanya memiliki satu pola dominan misalnya bahasa Indonesia yaitu SVO, bahasa Inggris memiliki dua pola dominan yaitu SVO, dan VSO. Tipologi urutan dasar ini merupakan kajian yang penting karena sejumlah fitur dan parameter lainnya dapat ditafsirkan dari urutan ketiga unsur dasar ini.

Secara universal, sukar menentukan subjek sebuah kalimat, karena beragamnya konstruksi dan posisi subjek itu dalam kalimat. Bahasa Latin, misalnya, tidak mementingkan posisi subjek. Sejauh nomina itu bertanda $\mathrm{N}+$ /-us/ dalam sebuah kalimat maka ia adalah subjek dari kalimat itu, tanpa mempersoalkan posisinya (free word order). Adapun penanda itu sendiri dikenal dengan penanda kasus (case marking) dalam bentuk morfologis (Song, 2001: 44; Yusdi, 2008:39). Perhatikan contoh berikut.
(1a) Paul-us salutat Petr-um
Paul-Sub menghormati Peter Obj
‘Paul menghormati Peter'
(1b) Petr- um salutat Paul-us
Peter Obj menghormati Paul-Subj
'Paul menghormati Peter'
(1c) Salutat Petr- um Paul-us menghormati Peter-Obj Paul-Subj 'Paul menghormati Peter'

Pada contoh $(1 \mathrm{a}, \mathrm{b}, \mathrm{c})$ terlihat bahwa subjek dapat terletak pada posisi di mana saja, sebab ada pemarkah kasus yang merujuk ke subjek gramatikal maupun objek gramatikalnya.

Contoh lain pada bahasa Malagasi di Madagaskar seperti pada contoh (2) berikut. Subjek adalah nomina atau frasa nomina yang terletak pada posisi akhir pada sebuah konstruksi sintaksis (Keenan, 1975: 252; Yusdi, 2008: 38).

\section{(2) Manasa lamba Rasoa \\ AKT-cuci pakaian Rasoa \\ 'rasoa mencuci pakaian'}

Para ahli bahasa telah menetapkan tipologi bahasa berdasarkan susunan word order pada fungsi sintaksis di satu pihak, dan pentopikan di pihak lain. Bahasa Inggris,misalnya, ditemukan sebagai salah satu bahasa yang bertipologi S-V-O, sebagai bahasa yang menonjolkan subjek. Artinya bahasa ini dalam konstruksi kalimat atau klausa menghadirkan subjek secara obligatoris, namun dapat menghasilkan kalimat topikal. Selanjutnya Verhaar (1989: 225) mengatakan bahwa bahasa Indonesia adalah bahasa yang menonjolkan topik dalam ragam lisan dan ragam informal; namun dalam ragam tulis dan ragam formal bahasa Indonesia sangat menonjolkan subjek. Perhatikan contoh berikut.

(3) a. I came to Tina's house

b. It's seven o'clock now

(4) a. Saya datang ke rumah Tina

b. Sekarang pukul tujuh.

Kedua kalimat (3) dan (4) di atas mempunyai pola sintaksis S-V-O dengan penojolan subjek. Pada kalimat (3b) kehadiran subjek pronominal ketiga verba be adalah wajib karena bahasa Inggris adalah bahasa yang menonjolkan subjek. Tidak demikian halnya pada bahasa Indonesia, tanpa subjek pun kalimat (4b) sudah gramatikal. Penghilangan subjek pada (3b) dan penambahan subjek pada (4b) akan menurunkan konstruksi kalimat yang tidak berterima seperti pada (5) berikut ini.

(5) a. Now is seven o'clock (tanpa subjek)

b. Ini sekarang adalah pukul sepuluh (dengan subjek)

Pelesapan konstruksi it is dalam bahasa Inggris menyebabkan kalimat itu tidak gramatikal karena bentuk now yang berkategori adverbial /keterangan waktu tidak dapat menduduki fungsi subjek da- 
lam bahasa Inggris. Sebaliknya dalam bahasa Indonesia kehadiran kopulatif ini bersifat redundan sehingga menyebabkan kalimat $(5 a, b)$ tidak berterima.

Penelitian ini ingin mengkaji fungsifungsi pragmatis Bahasa Pakpak Dairi (selanjutnya disebut BPD), sehingga akan dapat diketahui apakah BPD termasuk kelompok bahasa yang menonjolkan subjek (subject prominent language) atau kelompok bahasa yang menonjolkan topik (topic prominent languge). Penelaahan didasarkan pada kerangka teori tipologi bahasa tentang perbedaan antara bahasa yang menonjolkan subjek dengan bahasa yang menonjolkan topik (Li (ed), 1976: 457-489; Jufrizal,2007: 50 )

Comrie (1989:30) mengemukakan bahwa di samping terdapat perbedaan-perbedaan antarbahasa yang ada di dunia, pastilah ada ciri-ciri (properties) yang sama yang mungkin dapat dicermati untuk melihat keterkaitan dan persamaan antarbahasa tersebut (Song 2001: 2-4; Artawa 2011; Jufrizal 2007: 52). Dengan berasumsi pada pendapat Comrie tersebut, penelitian ini akan mengkaji tipologi BPD melalui 'penelusuran' fungsi-fungsi pragmatis dengan mengamati pola pentopikalan yang terdapat dalam BPD.

Solin (1998:112) menyatakan bahwa penutur BPD adalah penutur multilingualis yaitu BPD dan bahasa Batak Toba, di samping bahasa Indonesia. Bahasa Batak Toba dan bahasa Indonesia banyak dipakai/digunakan oleh penutur bahasa Pakpak yang beragama Kristen, yang merupakan agama mayoritas penduduk suku Pakpak Dairi. Hal ini disebabkan suku Pakpak yang beragama Kristen mayoritas menggunakan bahasa Batak Toba dalam acara keagamaan di gereja HKBP yang menjadi gereja pertama yang ada di daerah/tanah Batak (termasuk di daerah Pakpak) di Sumatera Utara. Pada beberapa tahun terakhir ini, baru ada berdiri GKPPD (Gereja Kristen Protestan Pakpak Dairi) yang menggunakan BPD.
Sementara itu, di perantauan, BPD sangat jarang digunakan, apalagi bila bertemu dengan suku bangsa Toba. Ada kecenderungan sikap generasi muda masyarakat penuturnya yang merasa rendah diri atau malu dianggap orang tak terpelajar jika menggunakan BPD. Mereka lebih suka menggunakan bahasa Indonesia dalam pergaulan sehari-hari, baik dalam lingkungannya sendiri, maupun di luar lingkungannya. Bahasa yang jarang digunakan lambat laun akan dapat menjadi bahasa yang bergeser (terkontaminasi) dan mati, demikian juga BPD ini. Kalau semakin jarang digunakan karena dominannya bahasa Toba, danjuga bahasa Indonesia, tidak mustahil BPD akan hilang dari "peredar$a^{\prime \prime}$. Harapannya hal itu tidak akan terjadi, agar bangsa Indonesia tidak akan kehilangan salah satu unsur budaya identitas suku bangsa.

Kajian tipologis terhadap BPD, sebagai salah satu bahasa daerah di Sumatera Utara (termasuk kelompok bahasa Austronesia Barat), cukup penting dan bernilai ilmiah untuk dilakukan. Hal ini disebabkan oleh kenyataan bahwa sampai saat ini masih terdapat banyak pendapat tentang pengelompokan secara tipologis bahasa-bahasa daerah di Indonesia (Artawa, 2011). Hal inilah yang mendorong dilakukan penelitian yang mengangkat BPD sebagai objek kajian, baik alasan pendokumentasian untuk menghindari dari kepunahan tanpa bekas, maupun karena alasan-alasan teoritis yang disebutkan sebelumnya.

Secara etimologis, kata tipologis berarti pengelompokan ranah (classification of domain). Pengertian tipologi bersinonim dengan istilah taksonomi. Istilah teknis tipologi yang masuk ke dalam linguistik mempunyai pengertian pengelompokan bahasa-bahasa berdasarkan ciri khas strukturnya. Di antara bentuk kajian tipologi linguistik pada periode awal yang terkenal adalah word order typology atau tipologi tata urut dasar yang dilakukan 
oleh Greenberg (Comrie, 1989:35). Kajian ini berusaha mencermati fitur-fitur dan ciri-ciri khas gramatikal bahasa-bahasa di dunia, dan membuat pengelompokan yang bersesuaian dengan parameter tertentu, yang dikenal dalam dunia linguistik sebagai kajian tipologi linguistik (linguistic typology). Hasil kajian seperti itu melahirkan tipologi bahasa, pengelompokan bahasa-bahasa dengan sebutan tertentu (Artawa, 1995; Jufrizal, 2004).

Pada tahun 1970-an terlihat adanya keperluan akan kajian yang lebih bersifat lintas bahasa, baik dalam linguistik teoritis maupun dalam bidang kajian bahasa secara empiris teori netral (Jufrizal, 2004: 61). Perkembangan teori dan pendekatan kajian lintas bahasa ini merupakan reaksi terhadap teori Tatabahasa TransformasiGeneratif yang cenderung didasarkan pada perilaku kebahasaan bahasa Inggris. Teori linguistik (tatabahasa) lain yang ada pada tahun 1970-an antara lain adalah Tatabahasa Relasional dan Tatabahasa Fungsional ( Dick,1978)

Mallison dan Blake (1981:4-5) menyebutkan bahwa penelitian generalisasi lintas bahasa atau kesemestaan bahasa (language universals) dikenal luas sebagai pokok pikiran utama di belakang penelitian tipologi skala besar. Seperti halnya dengan tipologi bahasa, semestaan bahasa meliputi juga ciri fonologis, morfologis, sintaksis. Ciri-ciri kebahasaan yang tidak meliputi semua atau hampir semua bahasa di dunia tidak akan diperhitungkan sebagai kesemestaan bahasa, tetapi akan berguna bagi tipologi bahasa. Sebab itu antara semestaan bahasa dan tipologi bahasa terdapat hubungan timbal balik, tetapi di pihak lain terdapat juga perbedaan yang jelas. Penelitian kesemestaan bahasa menghendaki kajian tipologis yang dilakukan secara silang seluas mungkin. Pada pertengahan abad ke 20, kajian tipologi dan kesemestaan bahasa dilakukan berdampingan .
Comrie (1989:30-32) juga menyebutkan bahwa terdapat saling keterkaitan antara kesemestaan bahasa dan tipologi karena keduanya berjalan bergandengan. Kajian kesemestaan bahasa berusaha menemukan: (1) perilaku dan sifat-sifat yang umum bagi semua bahasa manusia; (2) mencari/ menemukan kemiripan yang ada dalam lintas bahasa; dan (3) berusaha menetapkan batas-batas variasi dalam bahasa manusia. Selanjutnya penelitian tipologi berusaha (1) mengelompokkan bahasa-bahasa, yaitu menetapkan bahasabahasa ke kelompok/ tipe yang berbeda; (2) mengkaji perbedaan antara bahasa-bahasa; dan (3) mempelajari variasi-variasi bahasa manusia. Untuk menetapkan tipologi bahasa perlu ditetapkan parameter tertentu untuk mengelompokkan bahasa di dunia. Menetapkan tipologi bahasa diperlukan asumsi tentang kesemestaan bahasa. Istilah kesemestaan bahasa bukan berarti seluruh bahasa mempunyai fitur atau kasus yang sama, melainkan hanya bersifathampir keseluruhan (kecenderungan umum). Jadi istilah lain dari kesemestaan bahasa disebut juga generalisasi lintas bahasa.

Song (2001) menambahkan bahwa ada empat jenis tahap analisis tipologis, yaitu (i) penentuan fenomena yang akan dipelajari; (ii) pengelompokan tipologis fenomena yang sedang diteliti; (iii) merumuskan simpulan umum (generalisasi) atas pengelompokan tersebut; dan (iv) menjelaskan simpulan umum tersebut. Tipologi linguistik bukanlah teori tatabahasa, sebagaimana halnya teori TG atau teori tata bahasa lain yang dirancang untuk memodelkan bagaimana bahasa bekerja (Jufrizal, 2007:4). Tipologi linguistik adalah bentuk kajian ketatabahasaan yang bertujuan untuk mengidentifikasi pola-pola linguistik secara lintas bahasa dan hubungan antara pola-pola tersebut. Oleh karena itu, teori tipologi linguistik akan bersesuaian saja dengan teori tatabahasa yang ada. 
Hakekat (asal muasal) subjek adalah pertautan antara agen dan topik. Agen merupakan peran gramatikal yang didasarkan pada peran semantis, sedangkan topik adalah istilah pada fungsi pragmatis. Dalam penelitian ini, topik kalimat dibatasi berdasarkan apa yang dikemukakan oleh Comrie (1989:64). Menurutnya, topik kalimat adalah tentang apa kalimat itu, atau apa yang menjadi pembicaraan kalimat itu.

Kemudian Black (1990:5) memberi batasan topik sebagai 'apa yang dibicarakan' sebagai lawan dari sebutan/komen. Lebih jauh dikatakan oleh Blake bahwa topik itu biasanya 'informasi latar' atau (given information) dan secara khusus (dalam bahasa Inggris) dinyatakan sebagai subjek. Menurut Blake, topik dapat juga berada di luar klausa sebenarnya, ditandai dengan perubahan intonasi. Sejalan dengan itu Halliday (1994:25) menggunakan istilah struktur tema-rema. Tema diindikasikan oleh posisi di dalam klausa, yaitu diposisikan pada awal klausa. Tema adalah elemen yang berfungsi sebagai titik berangkatnya pesan (departure of message), sementara sisa pesan disebut rema. Selanjutnya Halliday menggunakan tema topikal, ditandai sebagai elemen pertama klausa yang dapat berupa partisipan, sirkumstan, atau proses. Setiap klausa harus berisi satu tema topikal. Menurut Halliday jika elemen pertama sebuah klausa deklaratif (bahasa Inggris) adalah subjek, maka tema topikal tersebut tak bermarkah, dan selain / bukan subjek disebut konstruksi bermarkah (tema yang tak lazim) .

Istilah topik dalam penelitian ini mengacu pada ketiga pendapat linguis di atas. Pada BPD tema yang adalah topik merupakan elemen pertama yang posisinya di awal klausa dan diisi oleh proses (pada klausa transitif), merupakan topik tak bermarkah. Dalam pengamatan, konstruksi bermarkah BPD ditandai dengan pemarkah mo dan ngo ditempatkan di belakang topik di samping penggunaan sress, tekanan dan nada yang tidak lazim.

Li dan Thomson (Li (ed), 1976; Jufrizal, 2004, 2007) memperkenalkan tipologi bahasa-bahasa yang didasarkan pada 'derajat penonjolan; subjek atau topik'. Menurutnya, sebuah bahasa dikatakan sebagai 'bahasa yang menonjolkan subjek' jika kalimat dasarnya paling baik diungkapkan sebagai mempunyai struktur 'subjek-predikat'. Sementara itu, bahasa yang menonjolkan topik akan mempunyai struktur kalimat dasar sebagai mempunyai struktur topik-komen. Pernyataan ini tidak menolak sama sekali bahwa bahasa yang menonjolkan subjek juga mempunyai topik dan bahasa yang menonjolkan topik juga mempunyai subjek.

Li dan Thompson dalam Jufrizal (2007: 151), mengusulkan pengelompokan bahasa-bahasa menjadi empat kelompok. Pertama, bahasa yang menonjolkan subjek (misalnya bahasa Inggris dan Jerman). Kedua, bahasa yang menonjolkan topik (misalnya bahasa Cina dan Lahu). Ketiga, bahasa yang sama-sama menonjolkan subjek dan topik ( misalnya bahasa Jepang dan Korea). Keempat, bahasa yang tidak menonjolkan subjek maupun topik (misalnya bahasa Tagalog dan Illocano)

Pengelompokan ini didasarkan pada tuntutan tipologis bahwa ada sejumlah bahasa yang dapat diperikan dengan baik berdasarkan topik dan ada pula sekelompok bahasa yang diperikan berdasarkan pengertian subjek. Bukan berarti bahwa subjek dan topik tidak berhubungan sama sekali karena subjek sesungguhnya adalah topik yang digramatikalkan. Kebanyakan sifat perilaku topik bersamaan dengan sifat perilaku subjek dalam sejumlah bahasa (Li (ed), 1976; Jufrizal, 2007: 150-151)

Sementara itu, sejumlah fitur dari bahasa yang menonjolkan topik, antara lain: (1) topiknya ditandai dalam struktur lahir; (2) kaidah penciptaan subjek seperti pemasifan jarang ditemukan; (3) konstruksi 'subjek ganda' yang berorientasi topik 
merupakan struktur kalimat dasar (Gundel ,1988 lewat Artawa ,1988:98)

Konstruksi topik-sintaksis secara tipologi, termasuk konstruksi 'subjek ganda' tercatat sebagai jenis kalimat dasar pada ragam baku bahasa-bahasa yang menonjolkan topik. Akan tetapi, konstruksi seperti itu hanya ada sebagai bentuk pilihan tertanda dalam bahasa yang secara nyata menonjolkan subjek. Menurut Artawa (1998:68), pendapat dan kajian yang dilakukan Gundel sehubungan dengan konstruksi topik-komen mendukung apa yang dikemukakan oleh Li (1976:467). Menurut mereka, bahasa Indonesia dikelompokkan sebagai bahasa yang menonjolkan subjek, namun bahasa Tagalog, salah satu bahasa rumpun bahasa Austronesia lainnya, merupakan bahasa yang tidak menonjolkan subjek maupun topik.

Ada kecenderungan yang disebut konstruksi subjek ganda mempunyai kedudukan khusus dalam bahasa-bahasa yang menonjolkan topik. Konstruksi kalimat keseluruhan dari bahasa-bahasa kelompok ini lazimnya adalah satu kalimat mempunyai dua FN yang berdekatan di sebelah kiri predikat; salah satu FN itu membawa fungsi 'topik' dan yang lain membawa fungsi 'subjek', sehingga memunculkan konstruksi subjek ganda. Mari dicermati contoh berikut ini yang diambil dari Li dan Thompson (1976:468).

(6a) Sekanawa tai ga oisili (Jepang) Ikan TOP penggigit merah SUB enak

'ikan (topik) penggigit merah enak'

(6b) Neiki shu yezi da(china)

Itu pohon daun-daun besar

'Pohon itu(topik), daun-daun besar'

Pada contoh-contoh di atas, topik dan subjek keduanya ada. Li dan Thompson menjelaskan bahwa pada (6a) topik dimarkahi oleh partikel wa dan subjek dimarkahi oleh ga. Pada (6b) Neiki shu adalah topik dan FN yezi merupakan subjek kalimat. Dalam kalimat ini topik dapat dibuang dari kalimat dengan jeda.
Topik pada contoh-contoh di atas berada pada posisi awal kalimat. Berkenaan dengan ini, konstruksi topik-komen dalam bahasa-bahasa yang menonjolkan topik merupakan konstruksi yang tak tertanda (unmarked construction), sedangkan pada bahasa-bahasa yang menonjolkan subjek konstruksi topik-komen merupakan konstruksi tertanda (marked construction).

Secara tradisional subjek sebuah kalimat dimaklumi sebagai unsur yang mengkhususkan tentang apa kalimat itu. Jika mengacu pada pendapat ini, dapat dikatakan bahwa kalimat pasif seharusnya dipahami sebagai hal-ihwal tentang 'pasien' bukan 'agen', karena pemasifan merupakan proses sintaksis yang memindahkan pasien menjadi subjek dan agen menjadi keterangan (adjunct). Dalam bahasa seperti bahasa Inggris, subjek lazimnya merupakan argumen awal (depan). Namun demikian, bukanlah berarti bahwa semua argumen awal adalah subjek. Ada konstruksi lain yang argumen awal tidak merupakan subjek kalimat. Konstruksi seperti ini dikenal sebagai pelepasan ke kiri (left-dislocation). Mari dicermati contohcontoh berikut ini (dikutip dari Artawa, 1998:68).

(7a) Mary, she came yesterday 'mary, dia datang kemarin'

(7b) Mary I know 'mary saya tahu'

Konstruksi (7a) adalah contoh dari apa yang disebut pelepasan ke kiri dan (7b) adalah contoh pentopikalan. Perbedaannya adalah pada konstruksi pelepasan ke kiri ada pronomina dalam klausa sebenarnya yang merujuk ke frasa nomina awal klausa tersebut, sedangkan pada konstruksi pentopikalan tidak demikian halnya. Pada (7a) pronomina she adalah anaforis, yang merujuk ke FN Mary.

Menurut Artawa (1998:68-70), bahasa Bali sebagai salah satu bahasa Austronesia mempunyai beberapa pola konstruksi pelepasan ke kiri sebagai berikut: 
(8) I Wayan, ia malajah jani ART Wayan 3TG belajar sekarang 'mengenai Wayan, ia belajar sekarang'

(9) Macan, anak mula galak harimau orang telah galak 'mengenai harimau, mereka biasanya galak'

(10) Murid-e ento, guru-ne ramah murid-DEF itu guru-POS3TG ramah 'mengenai murid itu, gurunya ramah'

(11) Sari, panak-ne ngeling Sari, anak-POS3TG tangis 'mengenai Sari, anaknya menangis'

(12) Anak-e ento, bapan-ne ngae umah orang -DEF itu bapak-POS3TG AKTbuat rumah 'mengenai orang itu, bapaknya membuat rumah'

Pola konstruksi pelepasan ke kiri pada (8) di atas adalah FN yang dilepaskan ke kiri bersifat definit (terbatas) dan diikuti oleh kalimat penuh yang subjeknya merujuk ke FN yang dilepaskan ke kiri tersebut dengan menggunakan bentuk pronomina. Pola yang sama juga dapat digunakan untuk nomina umum (biasa), seperti contoh (9). Pelepasan ke kiri dalam bahasa Bali juga dapat terjadi dalam hubungan pemilik-termilik antara FN yang dilepaskan ke kiri dengan subjek klausa yang mengikutinya. Ini dapat terjadi pada klausa bukan verbal (10) dan klausa verbal (11) dan (12)

Menurut Artawa (1998:70) pentopikalan sering dipahami sebagai proses pragmatis-sintaksis yang mengubah unsur bukan-topik menjadi topik. Unsur yang ditopikkan tersebut harus arguman inti, bukan unsur yang berelasi oblik (frasa yang mengungkapkan lokatif atau instrumen). Jika frasa berelasi oblik yang ditempatkan di awal kalimat, itu bukan apa yang dimaksud dengan pentopikalan, tetapi hanya dinamakan sebagai proses pengedepanan (fronting). Mari dicermati contoh sederhana tentang pengedepanan yang dikutip dari Artawa, (1998:70) berikut ini :

(13a) John bought some fruit in the market.

(13b) In the market, John bought some fruit

Lokatif in the market pada contoh (13a) bahasa Inggris di atas dikedepankan pada (13b). Artawa (1998:71) menyebutkan bahwa contoh (14b) berikut ini adalah sebuah proses pentopikalan dalam BB, yaitu pelengkap pasien ditopikkan. Hal ini disebabkan oleh kenyataan bahwa argumen inti buku-ne ento dikedepankan; unsur awal dari klausa itu adalah argumen inti.

(14a) Tiang ngaba buku- ne ento 1TG AKT-bawa buku-DEF itu 'saya membawa buku itu'

(14b) Buku-ne ento tiang ngaba buku-DEF itu 1TG bawa 'buku itu saya bawa'

Kerangka teoritis ini menjadi arah dan dasar analisis terhadap BPD, untuk penelusuran apakah BPD sebagai bahasa yang menonjolkan subjek atau menonjolkan komen atau sebagai bahasa yang tidak menonjolkan subjek maupun komen.

\section{METODE}

Penelitian ini menggunakan data lisan dan juga memanfaatkan data tulisan. Selain itu, peneliti memanfaatkan 'daya intuisi' sebagai penutur asli BPD untuk menambah sumber data yang diperlukan. Peneliti juga menjaring data lisan dengan menggunakan metode simak, yaitu dengan cara menyimak penggunaan BPD.

Karena merupakan penelitianyang bersifat deskripitif kualitatif, selain memberi gambaran apa adanya tentang sistem pentopikalan dalam BPD, juga diharapkan sampai pada penemuan dan perumusan pola-pola pentopikalan pada BPD sehingga dapat merujuk ke pengelompokan sistem tipologisnya. Metode yang digunakan dalam menganalisis data dalam penelitian ini adalah metode agih (Soe- 
daryanto, 1993: 15 dan Mahsun, 2011: 102-142). Dengan menggunakan teknik ganti dan teknik ubah-ujud dalam metode agih tersebut terhadap data unmarked construction dan marked construction dapat dipaparkan pola pentopikalan yang terdapat dalam BPD

\section{HASIL DAN PEMBAHASAN Struktur Dasar Klausa BPD}

Yang dimaksud dengan struktur dasar klausa dalam penelitian ini adalah struktur/konstruksi dasar dari klausa dasar. Sementara itu, klausa dasar adalah konstruksi klausa sedikitnya mempunyai ciriciri : (a) terdiri atas satu klausa; (b) unsurunsur intinya lengkap; (c) susunan unsurunsurnya menurut urutan yang paling umum; (d) tidak mengandung pertanyaan atau pengingkaran. Dengan kata lain, kalimat (klausa) dasar dalam penelitian ini sama dengan kalimat tunggal dekleratif, afirmatif yang unsur-unsurnya paling lazim (Alwi dkk, 2000: 313,319).

Sebagaimana halnya bahasa-bahasa lainnya (seperti bahasa Inggris), BPD mempunyai klausa dasar berpredikat verbal dan juga berpredikat bukan verbal. Untuk melihat struktur dasar klausa BPD yang berpredikat bukan verbal, akan disajikan contoh klausa untuk masing-masing jenis klausa yang ada dalam BPD

(15) Mlaga bapa ndai nai marah bapak dari tadi 'bapak marah dari tadi'

(16) Guru dakoli- na guru suami- POS3TG 'suaminya guru'

(17) Lima dukak bapa lima anak bapak 'anak bapak lima'

(18) I juma popung di sawah nenek 'nenek di sawah'

Pada (15) subjek klausa adalah bapa yang didahului oleh predikat ajektival mlaga dan keterangan ndai dan nai. Pada contoh ini, keterangan ndai dan nai bersifat manasuka. Jadi, inti klausa ini adalah bapa (subjek) dan ajektiva mlaga yang berfungsi sebagai predikat. Pada (16) subjeknya adalah dakolina dan guru adalah predikatnya; pada contoh (17) dukak bapa adalah subjek kalimat tersebut dan predikatnya adalah lima; dan pada (18) popung adalah subjek dan $i$ juma (frasa preposisionsl)sebagai predikat. Jadi pada struktur dasar klausa non-verbal BPD predikatnya diisi oleh kategori kategori kelas non verbal ; yaitu kategori adjektiva, nomina, numeral ( kata bilangan), dan frase preposisi.

Pada klausa verbal, ada beberapa hal yang perlu diperhatikan yang dapat dijadikan kerangka berpikir. Pertama, harus diamati jenis verba tersebut apakah transitif atau intransitif, kedua apakah ada afiks sebagai pemarkah pada verba tersebut, dan ketiga harus diamati jumlah argumen (frasa nominal) yang secara lazim terdapat dalam klausa tersebut

Klausa transitif BPD yang dibangun oleh kehadiran verba transitif pada posisi predikat, umumnya merupakan verba berafiks yaitu prefiks meN-(nasal). Verba transitif yang (mungkin) dapat muncul tanpa afiks pada klausa transitif tidak banyak jumlahnya. Verba transitif tanpa afiks ini pun jika dibubuhi afiks dapat berterima. Sehubungan ada atau tidak adanya afiks, verba transitif BPD dikelompokkan menjadi dua, yaitu verba transitif dengan atau tanpa afiks (VTr -/+ afiks) dan verba transitif wajib berafiks (VTr + afiks)

Berikutiniadalah contoh-contohklausa verbal dasar BPD

(19a) Meng-enum susu dukak - na V-O-S AKT-minum susu anak -POS3TG 'anaknya meminum susu'

(19b) Enum susu dukak- na V-O-S minum susu anak- POS3TG 'anaknya minum susu'

(20a) Men-cinar page puhun V-O-S AKT-jemur padi paman 'paman menjemur padi' 
(20b) * Cinar page puhun jemur padi paman 'paman jemur padi'

Pada contoh klausa yang ditandai dengan (19a) dan (b) di atas berterima. Ini terjadi karena kehadiran dan ketidakhadiran afiks pada verba masing-masing klausa tidak mempengaruhi struktur dasar klausa transitif tersebut. Struktur dasar klausa transitif (19b) tersebut tetap terdiri atas predikat, objek dengan atau tanpa keterangan, dan subjek. Konstruksi dengan atau tanpa afiks pada verba transitif tersebut menyiratkan bahwa dalam BPD ditemukan beberapa verba transitif yang dibubuhi afiks secara manasuka. Pada (20a) kehadiran afiks pada verba sangat diperlukan, sehingga kalimat (20b) merupakan kalimat yang tidak berterima karena tidak adanya afiks pada verba cinar

Kalimat deklaratif BPD berdasarkan temuan data penelitian ini mempunyai satu pola yang lazim yaitu pola urutan VOS. Di samping pola urutan tersebut, dalam BPD, dimungkinkan pula pola lain yang tidak lazim. Dengan demikian klausa/ujaran berikut masih berterima dalam BPD.

(21a) Me-nuan serpoh bapa ijuma V-O-S- (K) AKT-nanam pakis bapak di ladang 'menanam pakis bapak di ladang'

(21b) I juma me-nuan serpoh bapa (K)-V-O-S di ladang AKT-nanam pakis bapak 'bapak menanam pakis di ladang'

(21c) Bapame-nuan serpoh i juma S-V-O-(K) bapakAKT-nanam pakis di ladang 'bapak menanam pakis di ladang'

Klausa (21a) berpola urutan VOS, subjek terletak di belakang VO. Pada klausa (21b) berupa VOS, subjek terletak pada posisi di belakang VO. Frasa berpreposisi i juma dapat diletakkan di berbagai posisi dalam klausa BPD, kecuali di antara verba dan objeknya. Pada (21c) S klausa tersebut berada di depan VO.Jadi (21c) memiliki urutan SVO. Hal ini merupakan bentuk yang tidak lazim(marked construction) namun masih berterima dengan tekanan pada bagian bapa yang menjadi topik/ fokus kalimat tersebut. Selanjutnya perhatikan contoh-contoh berikut ini.

(22) Mer-demu kalak $i$ i sapo V-S- (K) AKT-jumpa mereka di rumah 'mereka berjumpa di rumah

(23) Me-morih oles -na namberu V-O-S AKT-cuci kain- POS3TG bibi 'mencuci kainnya bibi'

(24) Namberu me-morih oles- na S-V-O bibi AKT-cuci kain -POS3TG 'bibi mencuci kainnya'

(25) *Oles-na namberu me-morih kain-POS3TG bibiAKT-cuci 'kainnya bibi mencuci'

(26) Oles-na namberu porih O-S-V kain-POS3TGbibi cuci 'kainnya bibi cuci'

Dari contoh terlihat bahwa (22) adalah kalimat intransitif satu argumen, yaitu agen/paien yang berfungsi sebagai subjek gramatikal. kalaki merupakan agen/pasien, i sapo bukan merupakan objek gramatikal tetapi hanya sebagai instrumen yaitu sebagai keterangan tempat. Jadi memiliki urutan kata V-S-(K). Sementara kalimat (23) adalah kalimat transitif dengan dua argumen pos-verbal. Argumen pertama pos-verbal adalah pasien yang berfungsi sebagai objek gramatikal dan argumen kedua pos-verbal merupakan agen yang menjadi subjek gramatikal. Urutan VOS yang terlihat pada (23) merupakan urutan kata dasar dan secara gramatikal sebagai urutan yang paling lazim dan berterima. (Namun dalam BPD di samping urutan dasar VOS, ditemukan juga urutan $\mathrm{SVO}(\mathrm{K})$ seperti pada 21c). Pada bentuk predikat berupa verba asal, kalimat dengan tata urutan OSV juga ditemukan, walau dalam pemakaian lebih terbatas jumlahnya (contoh 26). Dalam (25) kalimat menjadi tidak gramatikal karena ( predikat) bukan verba dasar. Jadi dalam BPD ada satu tata urutan lazim yang berterima yaitu VOS, dan tata urutan lainnya yang tidak lazim 
yang masih berterima. Pola lazim artinya pada bentuk pola V-O-S.atau V-S tersebut (pada 22, 23) berdasarkan dominannya kalimat yang muncul karena seringnya digunakan, juga pola tersebut digunakan secara alamiah dan wajar, tanpa adanya penekanan pada unsur yang dipentingkan (unmarked construction). Pada kalimat dengan pola (24) dan (26) unsur namberu dan olesna mendapat penekanan khusus. Sejauh ini ternyata bahwa struktur dasar $\mathrm{V}-\mathrm{O}-\mathrm{S}$ pada BPD berbeda dengan struktur dasar bahasa-bahasa Pesisir lainnya seperti bahasa Melayu (bahasa Indonesia) dan bahasa Minangkabau yang memiliki struktur dasar dengan pola S-V-O.

\section{Pentopikalan Bahasa Papak-Dairi}

Seluk beluk relasi gramatikal suatu bahasa berhubungan dengan sejumlah konsep dan istilah sintaksis lainnya. Relasi gramatikal yang berupa S, O, (OTL) BPD mempuyai pola yang lazim digunakan oleh penutur-penuturnya. Pola urutan kata (word order) kalimat/klausa BPD dalam penelitian ini didasarkan pada pengertian urutan kata seperti dikemukakan Steele (1978) dalam Mallinson dan Blake, 1981: 121-124), yang menyebutkan bahwa bahasabahasa di dunia mempunyai konstruksi "subjek-predikat" (dan variasinya) sebagai dasar klausa/kalimat. Keberadaan objek dalam konstruksi klausa dasar juga menjadi penting karena dikaitkan dengan sifat-perilaku verba yang menempati predikat. Pengertian tata urutan kata BPD dalam penelitian ini merujuk ke 'urutan dasar', yakni urutan yang ada pada klausa netral, dan yang paling lazim digunakan, sebagai unmark construction. Relasi (dan peran) gramatikal tidak dapat dilepaskan dari kajian tentang struktur klausa/kalimat dalam bahasa tersebut. Berdasarkan data terhadap 200 kalimat deklaratif BPD, terdapat 190 kalimat yang berpola VOS, dan selebihnya ada pula 10 kalimat BPD berpola SVO.
(27) Men-jaka koran si Anggiat (V-O-S)

AKT-baca koran si Anggiat

'membaca koran si Anggiat'

(28) Ia ngo petandaken diri-na (S-V-O)

3TG T perkenalkan diri-POS3TG

'dia memperkenalkan dirinya'

Hal ini mengindikasikan bahwa dalam BPD word order yang lazim digunakan adalah pola urutan VOS. Dalam hal ini kelaziman diartikan sebagai kalimat netral yang merupakan unmark construction. Di samping itu ditemukan pula pola $\mathrm{S}-\mathrm{V}-\mathrm{O}$, (contoh 28) yang berupa marked construction. Jadi dalam klausa BPD, dimungkinkan posisi kata yang dipentingkan diletakkan pada posisi awal klausa/ ujaran. Dengan demikian ujaran/ klausa (contoh 28) berterima juga dalam BPD, dan pola marked ini lebih tepat dianalisis berdasarkan kajian pemusatan/pementingan (topik) yang lebih bersifat pragmatis.

Menurut Artawa (1998:70) pentopikalan sering dipahami sebagai proses pragmatis-sintaksis yang mengubah unsur bukan-topik menjadi topik. Unsur yang ditopikkan tersebut harus arguman inti. Argumen inti adalah unsur sintaksis yang kehadirannya dalam suatu klausa diperlukan oleh verba klausa tersebut dan tidak dimarkahi oleh preposisi/posposisi ataupun konjungsi. Jadi bukan unsur yang berelasi oblik (frasa yang mengungkapkan lokatif atau instrumen). Jika frasa berelasi oblik yang ditempatkan di awal kalimat, itu bukan apa yang dimaksud dengan pentopikalan, tetapi hanya dinamakan sebagai proses pengedepanan (fronting).

Analisis tentang pelepasan ke kiri (left-dislocation), pentopikalan (topicalisation), dan pengedepanan (fronting) dalam BPD akan mengacu pada pendapat dan kerangka kerja yang dikemukakan Artawa (1998). Analisis ini diharapkan dapat menemukan dan menyimpulkan apakah BPD termasuk bahasa yang menonjolkan subjek atau bahasa yang menonjolkan 
topik, atau kelompok yang lainya. Mari dicermati contoh berikut ini untuk melihat pelepasan ke kiri yang ada dalam BPD.

(29a) Popung Peang, i sapo ia nenek Peang, di rumah 3TG 'mengenai nenek Peang, dia di rumah'

(29b) Si Anggiat, me-nokor juma ia ART-Anggiat AKT-beli sawah 3TG 'mengenai Anggiat, dia membeli sawah'

(29c) Karambiri, mer-dabuh-en ia mi tanoh gambir DEF itu,AKT-jatuh-SUF 3TG di tanah 'mengenai gambir itu, ia berjatuhan ke tanah'

Frasa nomina (FN) yang dilepaskan ke kiri pada $(29 a, b, c)$ merupakan FN definit (dalam BPD nama orang/sapaan kehormatan/gelar/nomina umum keterbatasannya dapat tidak dimarkahi/kosong (29a), atau dimarkahi kata sandang/artikel si (contoh $29 b)$, atau dengan artikel $i$ (29c). FN tersebut diikuti kalimat utuh yang subjeknya merujuk ke FN yang dilepaskan ke kiri, dalam bentuk pronomina (bana, ia) .

Konstruksi pelepasan ke kiri (left dislocation) yang menunjukkan hubungan pemilik-termilik juga ditemukan dalam BPD. Maksudnya adalah konstruksi tersebut menunjukkan hubungan pemilik-termilik antara FN yang dilepaskan ke kiri dengan subjek klausa yang mengikutinya. Mari dicermati contoh berikut ini:

(30a) Juma i, mbueh reme- na sawah-ART, banyak padi-POS3TG 'mengenai sawah itu, banyak padinya'

(30b) Sapo i, timbo tataring- na rumah ART, tinggi dapur POS3TG 'mengenai rumah itu, tinggi dapurnya'

FN yang dilepaskan ke kiri dengan subjek klausa yang mengikutinya pada contoh $(30 \mathrm{a}, \mathrm{b})$ menunjukkan hubungan pemilik-termilik (possesor-possessee). Klausa sesungguhnya dari contoh-contoh di atas mempunyai predikat bukan verbal.

Konstruksi yang menunjukkan hubungan pemilik-termilik seperti ini juga dapat terjadi antara FN yang dilepaskan ke kiri dengan klausa berpredikat verbal. Mari dicermati contoh berikut ini:

(31a) Puhun Dora, anak daberu- na naeng mer-begas

paman Dora, anak perempuanPOS3TG akan AKT-menikah 'mengenai paman Dora, anak perempuannya akan menikah'

(31b) Kalakmora i, dukak-na me-nokor motor

orang kaya itu anak -POS3TG AKTbeli motor

'mengenai orang kaya itu,anaknya membeli motor'

(31c) Popung Tiamsa, poda- na i- bege kami

nenek Tiamsa, nasehat-POS3TG PAS-dengar kami

'mengenai nenek Tiamsa, nasehatnya kami dengar'

Ketiga klausa tersebut merupakan klausa berpredikat verbal (merbegas 'menikah', menokor'membeli', ibege 'didengar'); klausa (31a) adalah klausa intransitif, klausa (31b) adalah klausa transitif dengan konstruksi nasal, sedangkan (31c) merupakan klausa dengan verba konstruksi pasif.

Argumen inti BPD adalah unsur yang tidak bermarkah, sementara itu oblik BPD dimarkahi oleh preposisi. Relasi oblik dapat dilepaskan ke kiri melalui proses pengedepanan. Karena yang dilepaskan ke kiri bukan argumen inti, maka pelepasan ke kiri tersebut tidak disebut sebagai pentopikalan. Mari dicermati contoh-contoh berikut:

(32a) Me-ngelompa jagal inang i sapo puhun

AKT-masak daging ibu di rumah paman 
'ibu memasak daging di rumah paman'

(32b) I sapo puhun me-ngelompa jagal inang

di rumah paman AKT-masak daging ibu

'ibu memasak daging di rumah paman'

Frasa nomina berpreposisi $i$ sapo puhun merupakan oblik pada kalimat (32a). Relasi oblik tersebut dapat dilepaskan ke depan seperti (32b). Karena relasi oblik $i$ sapo puhun yang dikedepankan maka kalimat (32b) bukan konstruksi pentopikalan, tetapi disebut sebagai proses fronting atau pengedepanan. Contoh berikut ini menggambarkan pentopikalan dalam BPD

(33a) Menjaka surat bapa

AKT-baca surat bapak

'bapak membaca surat'

(33b) Surat bapa jaka

surat bapak baca

'bapak baca surat'

(34a) Mer-suan jelok namberu

AKT-tanam labu bibi

'menanam labu bibi'

(34b) Jelok namberu suan

labu bibi tanam

'labu bibi tanam'

Pada (33a) FN surat adalah argumen inti (objek/pasien) dan sama halnya FN jelok pada (34a). Kedua argumen inti tersebut menjadi unsur awal pada masingmasing klausa (33b) dan (34b). Dengan demikian objek/pasien dalam BPD dapat ditopikkan. Pentopikalan objek/pasien menyebabkan hilangnya pemarkah nasal pada verbanya dan tata urutan berubah menjadi O-S-V Pada $(33 b, 34 b)$ struktur tersebut bukanlah struktur dasar BPD namun merupakan struktur tertanda (marked construction)

Pengelompokan bahasa-bahasa berdasarkan pola topik/ subjek atau topik/ komen (Li dan Thompson dalam Jufrizal (2007:151), mengusulkan pengelompokan bahasa-bahasa menjadi empat kelompok: (1) kelompok bahasa bahasa yang menonjolkan subjek atau (2) kelompok bahasa yang menonjolkan topik atau (3) kelompok bahasa yang sama-sama menonjolkan subjek dan topik atau (4) kelompok bahasa yang tidak menonjolkan subjek dan tidak menonjolkan. Akhirnya harus dicermati bahwa BPD masuk dalam kelompok mana di antara keempat kelompok di atas.

Menurut Gundel (Jufrizal 2002:158) kaidah penciptaan subjek merupakan hal yang paling umum adanya dalam bahasabahasa yang menonjolkan subjek, seperti yang ditemui dalam bahasa Inggris. Dalam jenis bahasa seperti itu, struktur topik komen tidak menentukan struktur sintaksis secara khas. Kecenderungan untuk ungkapan yang merujuk ke topik yang terjadi pada posisi awal kalimat terjadi terutama sekali oleh adanya hubungan yang dekat antara subjek dan topik.

Salah satu sifat subjek gramatikal dalam BPD adalah bahwa subjek merupakan FN pertama pos-verbal (verba intransitif) dan FN kedua pos-verbal (verba transitif). Namun demikian, tidak berarti setiap FN kedua pos-verbal merupakan subjek bahasa ini. Pengaplikatifan-lokatif BPD pada contoh di bawah ini merupakan proses pentransitifan sehingga merupakan proses penciptaan objek.

(35a) Masuk pa tonga tu bages nami masuk pak tengah ke rumah POS3JM 'masuk pak tengah ke rumah kami'

(35b) Bages nami pa tonga masuki rumah POS3JM pakuda masuk-APL 'rumah kami pak tengah masuki

(36a) Men-dea kemenjen nantonga i onan

AKT-jual kemenyan ibu- Tengah di pasar

‘Menjual kemenyan ibu- Tengah di pasar'

(36b) I-onan kemenjen nantonga dea-i di pasar kemenyan bu Tengah jualAPL

'kemenyan ibu Tengah juali di pasar' 
(36c) Kemenjen nantonga dea -i i onan kemenyan ibu-Tengah jual-APL di pasar

'kemenyan dijuali ibu-Tengah di pasar'

Kalimat (35a) dan (36a), merupakan kalimat asal; pada kalimat ini bages nami dan $i$ onan merupakan unsur kalimat berelasi oblik. Proses pengaplikatifan struktur dasar dengan sufiks /-i/ pada(35b) menaikkan relasi oblik $i$ bages nami menjadi objek. Kaidah penciptaan objek juga diperlihatkan oleh (36b) dan (36c)

Selain itu, konstruksi aplikatif-instrumental dalam BPD juga merupakan kaidah penciptaan objek. Perhatikan contoh berikut.

(37a) kami eket kerbo $i$ dekket tali 3JM ikat kerbau itu dengan tali 'kami ikat kerbau itu dengan tali

(37b) Tali kami eket-ken i kerbo $i$ tali 3JM ikat-APL pada kerbau itu 'kami ikatkan kerbau itu dengan tali'

(37c) kami meng-eket-ken tali $i$ kerbo $i$ 3JM AKT-ikat-APL tali ke kerbau itu

'kami mengikatkan kerbau itu dengan tali'

Pada (37a) FN berpreposisi dekket tali adalah oblik. Relasi oblik tersebut menduduki posisi objek pada (37b) dan (37c) melalui pengaplikatifan dengan sufiks /-ken/

Jadi berdasarkan contoh dan uraian di atas, tampak bahwa konstruksi aplikatif BPD cenderung menuruti kaidah penciptaan objek. Kaidah penciptaan objek sering muncul pada proses pengaplikatifan. Namun harus dicatat bahwa struktur tersebut bukanlah struktur yang lazim, tapi merupakan struktur tertanda (mark construction). Merujuk ke pendapat Gundel dalam Artawa (1998:90), bahwa bila suatu bahasa produktif dalam kaidah penciptaan subjek dan pelepasan ke kiri merupakan struktur kalimat tertanda da- lam bahasa tersebut, maka ia digolongkan kepada bahasa yang menonjolkan subjek. Bahasa Inggris dan bahasa Bali termasuk dalam kelompok bahasa ini. Dalam hal ini, BPD berbeda dengan bahasa Bali, dan bahasa Inggris. BPD jelas bukan bahasa yang menonjolkan subjek, karena memiliki urutan dasar (unmarked construction) sebagai V-O-S (posisi urutan (S)ubjek sama sekali tidak ditonjolkan). Pentopikalan pasien/oblik merupakan struktur yang sering muncul dalam BPD, namun struktur kalimat tersebut merupakan struktur tertanda (marked construction). BPD bukan pula merupakan bahasa yang menonjolkan topik, sebab mengacu pada pendapat Gundel bahwa jika suatu bahasa disebut menonjolkan topik, apabila memiliki ciriciri :1) struktur topik tersebut merupakan struktur dasar, 2) topiknya ditandai dalam struktur lahir, 3) konstruksi 'subjek ganda' yang berorientasi topik merupakan struktur kalimat dasar, 4) kaidah penciptaan objek seperti pemasifan jarang terjadi pada bahasa tersebut. Keempat ciri tersebut tidak berlaku dalam BPD.

Pada BPD topik tidak ditandai oleh struktur lahir; struktur pentopikalan, hanya merupakan struktur alternatif dan turunan, bukan struktur dasar. Demikian juga konstruksi subjek ganda bukan struktur dasar, melainkan struktur turunan BPD. Di samping itu, semua tuturan/kalimat aktif BPD senantiasa dapat dipasifkan, sehingga proses pemasifan hal yang sangat lazim terjadi dalam BPD. Meskipun BPD dapat mentopikkan pasien/objek, akan tetapi konstruksi tersebut bukan konstruksi dasar.

Pentopikalan dalam BPD merupakan konsruksi alternatif dan turunan (unmark construction). Pentopikalan termasuk struktur kalimat tertanda dalam BPD, sama halnya dengan pelepasan ke kiri. Karena memenuhi persyaratan gramatikal yang lazim sebagai struktur dasar klausa BPD adalah konstruksi predikat - subjek, maka konstruksi predikat-subjek merupakan 
struktur kalimat tak tertanda (unmark construction). Hal ini mengindikasikan bahwa BPD termasuk ke dalam golongan kelompok bahasa yang keempat berdasarkan pengelompokan bahasa-bahasa di dunia, yaitu bahasa yang tidak menonjolkan subjek dan tidak menonjolkan topik sama halnya dengan bahasa Tagalog dan Illicano.

\section{SIMPULAN}

Berdasarkan uraian di atas dapat disimpulkan bahwa pentopikalan dapat dilakukan pada keadaan khusus oleh faktorfaktor pragmatis. Urutan kata yang lazim dalam BPD adalah VOS pentopikalan ditandai oleh hilangnya pemarkah nasal pada verba/predikat kalimat dan disertai berubahnya tata urutan BPD menjadi O-S-V. Pentopikalan merupakan struktur kalimat tertanda (marked costruction) BPD bukan merupakan struktur dasar. Mengacu pada pendapat Gundel BPD termasuk ke dalam kelompok bahasa yang bukan menonjolkan subjek dan bukan pula menonjolkan topik.

\section{UCAPAN TERIMA KASIH}

Artikel ini merupakan bagian dari disertasi penulis yang berjudul "Relasi dan Peran Gramatikal dalam Bahasa Pakpak Dairi: Kajian Tipologi". Untuk itu pada kesempatan ini, penulis mengucapkan terimakasih kepada : (1) Prof. Dr. Ir. A. Rahim Matondang, MSIE, selaku Direktur Sekolah Pascasarjana Universitas Sumatera Utara dan juga (2) Prof. Dr. Robert Sibarani, M.Si; Prof Dr. Jufrizal, M.Hum. dan Dr. Eddy Setia, M.Ed.TESP masing-masing selaku Promotor dan Co Promotor yang telah banyak membantu penulis menyelesaikan penelitian ini dengan memberi masukan dan koreksi yang sangat berguna; (3) juga beberapa rekan sejawat di Program Sastra Indonesia dan berbagai pihak yang namanya tak mungkin penulis sebutkan satu persatu. Semoga amal dan kebaikan Bapak, Ibu dibalas-Nya berlipat ganda.

\section{DAFTAR PUSTAKA}

Alwi, H. dkk. 2000. Tata Bahasa Baku Bahasa Indonesia. Jakarta: Balai Pustaka

Artawa, I Kt. 1995 b. “Teori Sintaksis dan Tipologi Bahasa" dalam Linguistika. Tahun II edisi. Denpasar: Program Magister (S2) Linguistik Universitas Udayana.

Artawa, I Kt. 1998. “Keergatifan Sintaksis dalam bahasa: Bahasa Bali, Sasak, dan Indonesia" dalam PELLBA 10 (Penyunting: Purwo, B. K.). Jakarta: Lembaga Bahasa Unika Atmajaya.

Artawa, I Kt. 2011. Bahasa Bali : Sebuah Kajian Tipologi Sintaksis. http: //www.ling. org.pages// diunduh 10 Mei 2012

Black B. J. 1990. Relational Grammar. London : Rouledge

Comrie, B.1989. Language Universals and Linguistic Typology. Oxford: Basil Blackwell Publisher Limited.

Dick, Simon C. 1978. Functional Grammar. Amsterdam: North Holland Publishing Company.

Halliday. 1994. An Introduction to Functional Grammar. London: Edward Arnold.

Jufrizal. 2004. "Struktur Argumen dan Aliansi Gramatikal Bahasa Minangkabau" (disertasi ). Denpasar: Program Doktor (S3). Linguistik Universitas Udayana.

Jufrizal. 2007. Tipologi Gramatikal Bahasa Minangkabau: Tataran Morfosintaksis. Padang: UNP Press.

Keenan, Edward, Bernard Comrie. 1975. "Noun Pharse accessibility and Universal Grammar." Linguistic Inquire.

Li, Charles N. 1976. Subject and Topic. Santa Barbara: University of California

Mahsun. 2011. Metode Penelitian Bahasa: Tahapan Strategi, Metode dan Tekniknya. Jakarta: Rajawali Press

Mallison, G. Blake, B.J. 1981. Language Tipology: Cross-Linguistics Studies in Syntax. Amsterdam: North Holland Publishing Company. 
Solin, Matsyuhito. 1988. Dalam Tradisi dan Perubahan: Konteks Masyarakat Pakpak Dairi. Medan: Monora.

Song, J. J. 2001. Linguistic Typology: Morphology and Syntax. Harlow, England: Pearson Education Limited

Sudaryanto. 1993. Metode dan Aneka Teknik Analisis Bahasa. Yogjakarta: Duta Wacana Press.
Vehaar, J.W.M. 1989. Teori Linguistik dan Bahasa Indonesia. Yogyakarta: Kanisius.

Yusdi, Muhammad. 2008. “Interaksi Topik Gramatikal dengan Pragmatik dalam Bahasa Indonesia" Dalam Lingua Didaktika. Volume 2, 38-50. 